\title{
Enhanced visible-light photocatalytic activity of Z-scheme graphitic carbon nitride/oxygen vacancy-rich zinc oxide hybrid photocatalysts
}

\author{
Yanan Liu a, Ruixia Wang b, Zhengkun Yang a, Hong Du a, Yifan Jiang a, Congcong Shen a, \\ Kuang Liang a, Anwu Xu a,* \\ a Division of Nanomaterials and Chemistry, Hefei National Laboratory for Physical Sciences at Microscale, University of Science and Technology of China, \\ Hefei 230026, Anhui, China \\ ${ }^{\mathrm{b}}$ Department of Materials and Chemical Engineering, College of Chi Zhou, Chizhou 247100, Anhui, China
}

\section{A R T I C L E I N F O}

\section{Article history:}

Received 16 August 2015

Accepted 25 September 2015

Published 20 December 2015

\section{Keywords:}

Oxygen deficient zinc oxide

Graphitic carbon nitride

Hybrid photocatalysts

Photodegradation

Z-scheme

\begin{abstract}
A B S T R A C T
With the objectives of enhancing the stability, optical properties and visible-light photocatalytic activity of photocatalysts, we modified oxygen vacancy-rich zinc oxide $\left(\mathrm{V}_{\mathrm{o}}-\mathrm{ZnO}\right)$ with graphitic carbon nitride $\left(\mathrm{g}-\mathrm{C}_{3} \mathrm{~N}_{4}\right.$ ). The resulting g- $\mathrm{C}_{3} \mathrm{~N}_{4} / \mathrm{V}_{\mathrm{o}}-\mathrm{ZnO}$ hybrid photocatalysts showed higher visible-light photocatalytic activity than pure $\mathrm{V}_{0}-\mathrm{ZnO}$ and g- $\mathrm{C}_{3} \mathrm{~N}_{4}$. The hybrid photocatalyst with a g- $\mathrm{C}_{3} \mathrm{~N}_{4}$ content of $1 \mathrm{wt} \%$ exhibited the highest photocatalytic degradation activity under visible-light irradiation $(\lambda$ $\geq 400 \mathrm{~nm}$ ). In addition, the $\mathrm{g}-\mathrm{C}_{3} \mathrm{~N}_{4} / \mathrm{V}_{0}-\mathrm{ZnO}$ photocatalyst was not deactivated after five cycles of methyl orange degradation, indicating that it is stable under light irradiation. Finally, a Z-scheme mechanism for the enhanced photocatalytic activity and stability of the $\mathrm{g}_{-} \mathrm{C}_{3} \mathrm{~N}_{4} / \mathrm{V}_{\mathrm{o}}-\mathrm{ZnO}$ hybrid photocatalyst was proposed. The fast charge separation and transport within the g- $\mathrm{C}_{3} \mathrm{~N}_{4} / \mathrm{V}_{0}-\mathrm{ZnO}$ hybrid photocatalyst were attributed as the origins of its enhanced photocatalytic performance.
\end{abstract}

(C) 2015, Dalian Institute of Chemical Physics, Chinese Academy of Sciences. Published by Elsevier B.V. All rights reserved.

\section{Introduction}

Contamination of water systems by organic chemicals poses a serious environmental threat. The severity of this threat originates from the toxicity of organic chemicals to animals and humans. To meet the increasing demands to protect the environment, highly effective, inexpensive and stable photocatalysts for degradation of organic chemicals are strongly desired. Over the past decades, semiconductor photocatalysis has attracted extensive attention because it has a great potential to solve such environmental issues [1-4]. To date, various metal oxide semiconductors with different structures, morphologies and sizes, such as titanium dioxide [5], tin dioxide [6], cuprous oxide [7] and ferric oxide [8], have been extensively developed for photocatalytic applications. Among semiconductor materials, zinc oxide $(\mathrm{ZnO})$ is a promising candidate as a photocatalyst because of its low cost, non-toxicity and high efficiency in the photocatalytic degradation of organic pollutants $[9,10]$. Unfortunately, because of its wide band gap of $3.24 \mathrm{eV}$ at $27{ }^{\circ} \mathrm{C}$ [11], electron-hole pairs can only be effectively generated by ultraviolet (UV) light, which composes only about $4 \%$ of the solar spectrum. As a result, considerable effort has been devoted to improving the photoactivity of $\mathrm{ZnO}$ and extending its light absorption into the visible region using approaches such as dop-

\footnotetext{
* Corresponding author. Tel/Fax: +86-551-63602346; E-mail: anwuxu@ustc.edu.cn This work was supported by the National Basic Research Program of China (2011CB933700) and the National Natural Science Foundation of China (21271165).
} DOI: 10.1016/S1872-2067(15)60985-8 | http://www.sciencedirect.com/science/journal/18722067 | Chin. J. Catal., Vol. 36, No. 12, December 2015 
ing [12], semiconductor coupling [13,14], and deposition of metals [15].

An effective method to realize visible-light excitation is to introduce intermediate energy levels between the conduction band (CB) and valence band (VB) by doping semiconductors with metal or nonmetal elements. However, traditional impurity incorporation will lead to an increased content of recombination centers for the electron-hole pairs. Because it does not introduce any impurity elements, the introduction of oxygen vacancies is considered an effective way to preserve the intrinsic crystal structure of $\mathrm{ZnO}$ while extending its visible-light absorption, which leads to enhanced photocatalytic performance under visible-light irradiation [16,17]. Despite these efforts, the low separation efficiency of electron-hole pairs and serious photocorrosion in long-term photocatalytic processes still limit the practical application of $\mathrm{ZnO}$-based catalysts [18]. To improve the photocatalytic efficiency of $\mathrm{ZnO}$-based catalysts, it is important to overcome the drawbacks of $\mathrm{ZnO}$, which may be achieved by using a molecular electron-relay semiconductor or efficient electron transport matrix, such as polyaniline or graphene $[19,20]$. These delocalized conjugated materials match well with the $\mathrm{ZnO}$ photocatalyst in terms of energy levels, and a strong interfacial hybrid effect emerged between the materials, resulting in rapid charge separation and slow charge recombination in the electron-transfer process.

The metal-free polymeric semiconductor material graphitic carbon nitride $\left(\mathrm{g}-\mathrm{C}_{3} \mathrm{~N}_{4}\right)$ has attracted considerable attention since its photocatalytic performance was first reported by Wang et al. [21,22]. Research has shown that $\mathrm{g}-\mathrm{C}_{3} \mathrm{~N}_{4}$ has good thermal and chemical stability $[23,24]$, as well as excellent photoelectric properties [25]. However, the high recombination rate of photogenerated carriers currently limits the practical application of g- $_{3} \mathrm{~N}_{4}$ [26,27]. To enhance its photocatalytic capability, it was proposed that hybridizing $\mathrm{g}-\mathrm{C}_{3} \mathrm{~N}_{4}$ as a $\pi$-conjugated material with inorganic semiconductors could effectively promote photocatalytic activity and visible-light response [28,29]. The unique electronic properties, high specific surface area and locally conjugated aromatic system of g- $\mathrm{C}_{3} \mathrm{~N}_{4}$ make it an ideal candidate as a visible-light photocatalyst. Therefore, the combination of $\mathrm{ZnO}$ and $\mathrm{g}-\mathrm{C}_{3} \mathrm{~N}_{4}$ may be an ideal system to minimize the recombination of photogenerated electron-hole pairs in electron-transfer process and enhance photocatalytic activity.

In this work, we report oxygen-deficient $\mathrm{ZnO}$ modified with g- $\mathrm{C}_{3} \mathrm{~N}_{4}$ (denoted as $\mathrm{g}-\mathrm{C}_{3} \mathrm{~N}_{4} / \mathrm{V}_{\mathrm{o}}-\mathrm{ZnO}$ ), which was fabricated by annealing $\mathrm{Zn}(\mathrm{OH}) \mathrm{F}$ and melamine precursors in $\mathrm{N}_{2}$. The photocatalytic properties of the as-prepared g- $\mathrm{C}_{3} \mathrm{~N}_{4} / \mathrm{V}_{\mathrm{o}}-\mathrm{ZnO}$ composites under visible-light irradiation were examined.

\section{Experimental}

\subsection{Materials}

Zinc acetate dihydrate $\left(\mathrm{Zn}(\mathrm{AC})_{2} \cdot 2 \mathrm{H}_{2} \mathrm{O}\right)$, hexamethylenetetramine (HMT), hydrofluoric acid (HF, $40 \mathrm{wt} \%)$, melamine, methyl orange (MO), terephthalic acid (TA), sodium hydroxide $(\mathrm{NaOH})$ and humic acid (HA) were purchased from Sinopharm
Chemical Reagent Co. Ltd (Shanghai, China). All reagents were of analytical grade and used as received without any further treatment.

\subsection{Synthesis of $\mathrm{Zn}(\mathrm{OH}) \mathrm{F}$ precursor}

$\mathrm{Zn}(\mathrm{OH}) \mathrm{F}$ was prepared according to our previous report [30]. In a typical procedure, $\mathrm{Zn}(\mathrm{AC})_{2} \cdot 2 \mathrm{H}_{2} \mathrm{O}(5 \mathrm{mmol})$ was dissolved in deionized water $(30 \mathrm{~mL})$, and then HMT (5 mmol) was added under stirring. The resulting mixture was subjected to vigorous magnetic stirring at room temperature for $10 \mathrm{~min}$. Then an aqueous solution of $\mathrm{HF}(40 \mathrm{wt} \%, 300 \mu \mathrm{L})$ was gradually added under constant stirring. The mixture was transferred into a Teflon-lined stainless steel autoclave with a capacity of $50 \mathrm{~mL}$, and maintained at $160{ }^{\circ} \mathrm{C}$ for $6 \mathrm{~h}$. After cooling to room temperature naturally, the white product $\mathrm{Zn}(\mathrm{OH}) \mathrm{F}$ was collected by centrifugation, washed with deionized water and ethanol several times and then dried at $60{ }^{\circ} \mathrm{C}$ overnight in a vacuum oven.

\subsection{Synthesis of photocatalysts}

Appropriate amounts of melamine and $\mathrm{Zn}(\mathrm{OH}) \mathrm{F}$ were ground in a mortar for $20 \mathrm{~min}$. The mixture was then heated to $550{ }^{\circ} \mathrm{C}$ at a heating rate of $5{ }^{\circ} \mathrm{C} / \mathrm{min}$ and kept at this temperature for $3 \mathrm{~h}$ under $\mathrm{N}_{2}$. The nominal contents of g- $\mathrm{C}_{3} \mathrm{~N}_{4}$ to $\mathrm{V}_{\mathrm{o}}-\mathrm{ZnO}$ investigated were $0.5,1$ and $2 \mathrm{wt} \%$, and the obtained samples are denoted as $0.5 \mathrm{wt} \% \mathrm{~g}-\mathrm{C}_{3} \mathrm{~N}_{4} / \mathrm{V}_{\mathrm{o}}-\mathrm{ZnO}, 1 \mathrm{wt} \% \mathrm{~g}-\mathrm{C}_{3} \mathrm{~N}_{4} / \mathrm{Vo}-\mathrm{ZnO}$ and $2 \mathrm{wt} \% \mathrm{~g}-\mathrm{C}_{3} \mathrm{~N}_{4} / \mathrm{V}_{\mathrm{o}}-\mathrm{ZnO}$, respectively. Pure $\mathrm{V}_{\mathrm{o}}-\mathrm{ZnO}$ was prepared by calcination of $\mathrm{Zn}(\mathrm{OH}) \mathrm{F}$ in the absence of melamine, and $\mathrm{g}-\mathrm{C}_{3} \mathrm{~N}_{4}$ was obtained by annealing melamine following a similar procedure.

\subsection{Photocatalyst characterization}

X-ray diffraction (XRD) patterns were obtained on a Rigaku/Max-3A X-ray diffractometer with $\mathrm{Cu} K_{\alpha}$ radiation $(\lambda=$ $1.54178 \AA$ ) using an operation voltage and current of $40 \mathrm{kV}$ and $200 \mathrm{~mA}$, respectively. Transmission electron microscopy (TEM) and high-resolution transmission electron microscopy (HRTEM) were conducted using a JEOL-2010 microscope at an accelerating voltage of $200 \mathrm{kV}$. Room-temperature ultraviolet-visible (UV-vis) absorption spectra were recorded on a Shimadzu spectrophotometer (2501PC). Fourier transform infrared (FT-IR) spectra were measured on a Bruker Vector 22 FT-IR spectrometer at room temperature. X-ray photoelectron spectroscopy (XPS) was performed using a Perkin-Elmer RBD upgraded PHI-5000C ESCA system. Electron paramagnetic resonance (EPR) spectra were obtained using a Bruker EMX plus spectrometer operating at X-band frequencies $(9.4 \mathrm{GHz})$ at 130 K. A spectrofluorometer (F-4600, Hitachi, Japan) with a xenon discharge lamp excitation was used to measure the fluorescence signal of 2-hydroxyterephthalic acid (TAOH).

\subsection{Photocatalytic activity measurement}

The photocatalytic activities of the samples were measured 
by degradation of MO and HA under visible-light irradiation at room temperature. The light source was a 300-W Xe lamp (PLS-SXE300/300UV, Trusttech Co., Ltd., Beijing). A 150-mL double-layer beaker with a diameter of $6 \mathrm{~cm}$ was used as the reaction vessel. First, photocatalyst (50 mg) was dispersed in an aqueous solution of $\mathrm{MO}$ or HA $(10 \mathrm{mg} / \mathrm{L}, 50 \mathrm{~mL})$ in the reactor, which was cooled by running water to keep the temperature constant. Prior to light irradiation, the suspension was magnetically stirred in the dark for 30 min to reach adsorption-desorption equilibrium between the photocatalyst and MO/HA. Then, the stirred suspension was irradiated with a Xe lamp through a UV-cutoff filter $(\lambda \geq 400 \mathrm{~nm})$. The distance between the light source and reactor was $10 \mathrm{~cm}$. Aliquots $(4 \mathrm{~mL})$ of the solution were taken at given time intervals that were subsequently centrifuged and then filtered through a $0.22-\mu \mathrm{m}$ membrane filter to remove the remaining photocatalyst particles. The degradation of MO/HA was analyzed with a UV 1800PC spectrophotometer (Shanghai Mapada Instruments). Additionally, to test photocatalyst durability, recycling experiments for five consecutive cycles were performed. After each cycle, the catalyst was centrifuged, washed thoroughly with distilled water and ethanol several times to remove residual pollutant impurities, and then dried at $60^{\circ} \mathrm{C}$ before reuse.

Photoluminescence (PL) spectra with TA as a probe molecule were used to examine the formation of hydroxyl radicals $(\cdot \mathrm{OH})$ on the surface of the photocatalysts under visible-light irradiation. The experiments were performed as follows: photocatalyst (50 mg) was suspended in an aqueous solution (50 $\mathrm{mL}$ ) containing of $\mathrm{NaOH}(0.15 \mathrm{~g})$ and $\mathrm{TA}(3 \mathrm{mmol} / \mathrm{L})$ at room temperature. After irradiation for $15 \mathrm{~min}$, a $4.0 \mathrm{~mL}$ aliquot of solution was taken out and centrifuged. The fluorescence spectrum of the sample was measured using an excitation wavelength of $320 \mathrm{~nm}$. During the photoreactions, oxygen was not bubbled into the suspension.

\section{Results and discussion}

\subsection{Characterization of photocatalysts}

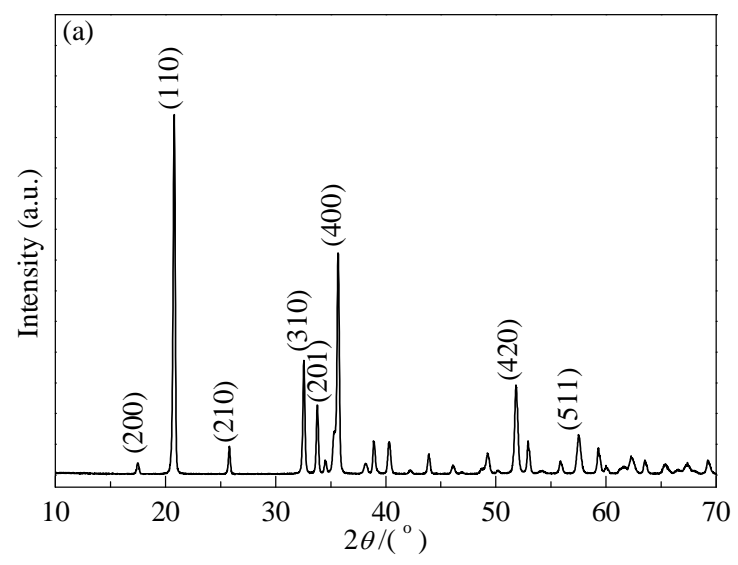

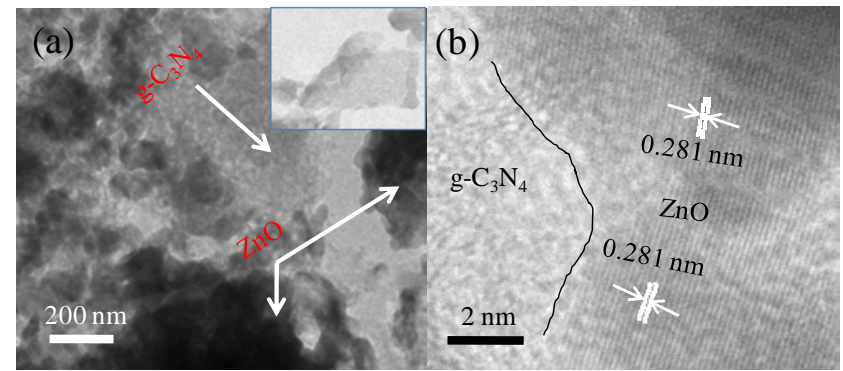

Fig. 2. TEM (a) and HRTEM (b) images of $1 \mathrm{wt} \% \mathrm{~g}-\mathrm{C}_{3} \mathrm{~N}_{4} / \mathrm{V}_{0}-\mathrm{ZnO}$.

The crystal structures of the $\mathrm{Zn}(\mathrm{OH}) \mathrm{F}$ precursor and g- $\mathrm{C}_{3} \mathrm{~N}_{4} / \mathrm{V}_{\mathrm{o}}-\mathrm{ZnO}$ products were determined by XRD. The XRD profile for $\mathrm{Zn}(\mathrm{OH}) \mathrm{F}$ is given in Fig. 1(a); all diffraction peaks can be indexed to orthorhombic-phase $\mathrm{Zn}(\mathrm{OH}) \mathrm{F}$ (JCPDS 32-1469). The XRD patterns of g- $\mathrm{C}_{3} \mathrm{~N}_{4}$, oxygen vacancy-rich $\mathrm{ZnO}$ (denoted $\mathrm{V}_{\mathrm{o}}-\mathrm{ZnO}$ ) and g- $\mathrm{C}_{3} \mathrm{~N}_{4} / \mathrm{V}_{\mathrm{o}}-\mathrm{ZnO}$ composites with different nominal contents of $\mathrm{g}-\mathrm{C}_{3} \mathrm{~N}_{4}$ are shown in Fig. 1(b). Two pronounced peaks are observed for pure g- $\mathrm{C}_{3} \mathrm{~N}_{4}$. The first peak at $13.10^{\circ}$ is associated with the in-plane structural packing motif, and the second at $27.39^{\circ}$ originates from interlayer stacking of the conjugated aromatic system [31]. The obtained $\mathrm{ZnO}$ nanoparticles (NPs) exhibit strong, sharp diffraction peaks, indicating they are highly crystalline. The diffraction peaks within the angular range $(2 \theta)$ of $10^{\circ}-70^{\circ}$ can be indexed to the hexagonal phase of ZnO (JCPDS 65-3411). No obvious characteristic peaks of $\mathrm{g}-\mathrm{C}_{3} \mathrm{~N}_{4}$ are detected in the diffraction patterns of the three g- $\mathrm{C}_{3} \mathrm{~N}_{4} / \mathrm{V}_{\mathrm{o}}-\mathrm{ZnO}$ hybrid photocatalysts, which is attributed to the relatively low content of $\mathrm{g}-\mathrm{C}_{3} \mathrm{~N}_{4}$ in the final catalysts $(0.5-2$ wt\%).

The microstructure of the $1 \mathrm{wt} \% \mathrm{~g}-\mathrm{C}_{3} \mathrm{~N}_{4} / \mathrm{V}_{\mathrm{o}}-\mathrm{ZnO}$ sample was characterized by TEM and HRTEM. Fig. 2(a) reveals that g- $\mathrm{C}_{3} \mathrm{~N}_{4}$ nanosheets are hybridized with $\mathrm{V}_{\mathrm{o}}$-ZnO NPs. A clear interface boundary is formed between $\mathrm{g}-\mathrm{C}_{3} \mathrm{~N}_{4}$ nanosheets and $\mathrm{V}_{\mathrm{o}}-\mathrm{ZnO}$ NPs upon calcination. This intimate contact should aid the transfer of photogenerated carriers between $g-\mathrm{C}_{3} \mathrm{~N}_{4}$ and $\mathrm{V}_{\mathrm{o}}-\mathrm{ZnO}$ and thereby promote the separation of photogenerated electron-hole pairs. The inset image in Fig. 2(a) shows a g- $\mathrm{C}_{3} \mathrm{~N}_{4}$ nanosheet. The HRTEM image in Fig. 2(b) clearly shows the

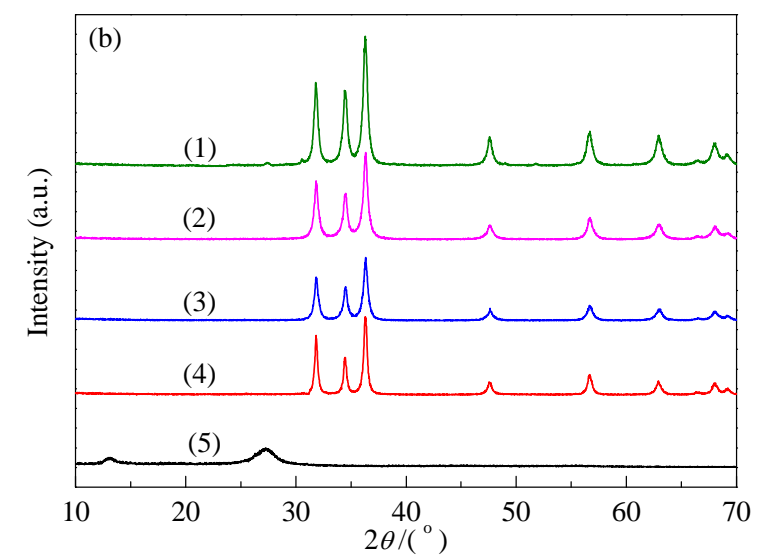

Fig. 1. XRD patterns of $\mathrm{Zn}(\mathrm{OH}) \mathrm{F}(\mathrm{a})$ and the catalysts (b). (1) $0.5 \mathrm{wt} \% \mathrm{~g}_{-} \mathrm{C}_{3} \mathrm{~N}_{4} / \mathrm{V}_{\mathrm{o}}-\mathrm{ZnO}$; (2) $1 \mathrm{wt} \% \mathrm{~g}-\mathrm{C}_{3} \mathrm{~N}_{4} / \mathrm{V}_{\mathrm{o}}-\mathrm{ZnO}$; (3) $2 \mathrm{wt} \% \mathrm{~g}-\mathrm{C}_{3} \mathrm{~N}_{4} / \mathrm{V}_{\mathrm{o}}-\mathrm{ZnO}$; (4) $\mathrm{V}_{\mathrm{o}}-\mathrm{ZnO}$; (5) g- $\mathrm{C}_{3} \mathrm{~N}_{4}$. 
lattice structure of $\mathrm{V}_{\mathrm{o}}-\mathrm{ZnO}$, indicating it is highly crystalline. The measured interplanar spacing of $\mathrm{V}_{\mathrm{o}}-\mathrm{ZnO}$ is $0.281 \mathrm{~nm}$, which corresponds to the $\mathrm{ZnO}(100)$ plane.

XPS measurements were carried out to characterize the elemental chemical states of 1 wt $\%$ g- $\mathrm{C}_{3} \mathrm{~N}_{4} / \mathrm{V}_{\mathrm{o}}-\mathrm{ZnO}$; high-resolution spectra of Zn $2 p, 01 s, \mathrm{C} 1 s$ and $\mathrm{N} 1 s$ are presented in Fig. 3(a)-(d), respectively. In the Zn $2 p$ spectrum, the major peak at $1021.75 \mathrm{eV}$ for $2 p_{3 / 2}$ indicates that $\mathrm{Zn}^{2+}$ is present in $\mathrm{V}_{\mathrm{o}} \mathrm{ZnO}$ [32]. The peak at $530.40 \mathrm{eV}$ in the $01 \mathrm{~s}$ spectrum can be assigned to lattice oxygen present in $\mathrm{ZnO}$ [33]. Meanwhile, the peak at $531.65 \mathrm{eV}$ is consistent with the presence of $\mathrm{O}^{2-}$ in the oxygen-deficient regions in the $\mathrm{ZnO}$ matrix [34], indicating the formation of oxygen vacancies. The high-binding-energy component located at $532.55 \mathrm{eV}$ is attributed to the presence of loosely bound oxygen on the surface of $\mathrm{ZnO}$ [35]. XPS analysis revealed that the 0 content of $1 \mathrm{wt} \%$ g- $\mathrm{C}_{3} \mathrm{~N}_{4} / \mathrm{V}_{\mathrm{o}}-\mathrm{ZnO}(38.2 \%)$ was lower than that of $\mathrm{V}_{\mathrm{o}}-\mathrm{ZnO}(41.8 \%)$. That is, the concentration of oxygen vacancies is increased after hybridization with $\mathrm{g}-\mathrm{C}_{3} \mathrm{~N}_{4}$, which may affect the optical properties of the material.

The $\mathrm{C} 1 \mathrm{~s}$ spectrum of $1 \mathrm{wt} \%$ g- $\mathrm{C}_{3} \mathrm{~N}_{4} / \mathrm{V}_{\mathrm{o}}-\mathrm{ZnO}$ (Fig. 3(c)) can be deconvoluted into two peaks at 284.50 and $285.40 \mathrm{eV}$. The peak at $284.50 \mathrm{eV}$ is attributed to adventitious carbon on the surface of $1 \mathrm{wt} \% \mathrm{~g}-\mathrm{C}_{3} \mathrm{~N}_{4} / \mathrm{V}_{\mathrm{o}}-\mathrm{ZnO}$, while that at $285.40 \mathrm{eV}$ is assigned to $\mathrm{C}=\mathrm{N}-\mathrm{C}$ coordination. Fig. 3(e) reveals that no signals from $\mathrm{N}$ species were observed for pure $\mathrm{V}_{\mathrm{o}}-\mathrm{ZnO}$. After hybridization with g- $\mathrm{C}_{3} \mathrm{~N}_{4}$, a weak, broad asymmetric peak corresponding to $\mathrm{N} 1 s$ was observed (Fig. 3(d)), suggesting that more than one chemical state of $\mathrm{N}$ exists. The broad peak of $\mathrm{N}$ $1 s$ was deconvoluted into four peaks with binding energies of 396.10, 398.40, 399.40 and $400.30 \mathrm{eV}$. The peak at $396.10 \mathrm{eV}$ corresponds to the substitution of a few $\mathrm{N}$ atoms in the $\mathrm{O}$ sublattice, which behave as an acceptor. The peak at $398.40 \mathrm{eV}$ was attributed to aromatic $\mathrm{N}$ bonded to two $\mathrm{C}(\mathrm{C}=\mathrm{N}-\mathrm{C})$ in the triazine or heptazine rings, while those at 399.40 and $400.30 \mathrm{eV}$ correspond to tertiary nitrogen $\mathrm{N}-(\mathrm{C})_{3}$ and $\mathrm{Zn}-\mathrm{O}-\mathrm{N}$, respectively. The peak consistent with $\mathrm{Zn}-\mathrm{O}-\mathrm{N}$ indicates that $\mathrm{g}-\mathrm{C}_{3} \mathrm{~N}_{4}$ and $\mathrm{V}_{\mathrm{o}}-\mathrm{ZnO}$ interact strongly in the photocatalyst because of calcination. The $\mathrm{C} 1 s$ and $\mathrm{N} 1 s$ binding energies of the photocatalyst are consistent with previously reported XPS data [36-40]. Moreover, C $1 s$ and N $1 s$ peaks originating from the g- $\mathrm{C}_{3} \mathrm{~N}_{4}$ phase are observed in the hybrid composite photocatalysts (Fig. 3(e)), confirming the presence of g- $\mathrm{C}_{3} \mathrm{~N}_{4}$. The XPS results are in good accordance with the TEM measurements. To investigate the energy band structure of $\mathrm{V}_{\mathrm{o}} \mathrm{ZnO}$, VB XPS near the Fermi level was measured, as shown in Fig. 3(f). The VB edge determined for $\mathrm{V}_{\mathrm{o}}-\mathrm{ZnO}$ was $2.73 \mathrm{eV}$, which is higher than the redox potential of $\mathrm{OH}^{\circ} / \mathrm{OH}^{-}(+1.99 \mathrm{eV})$. This implies that the $\mathrm{VB}$ of $\mathrm{V}_{\mathrm{o}}$-ZnO has strong water oxidation capability to generate active species such as $\mathrm{OH} \bullet$ by reaction with $\mathrm{H}_{2} \mathrm{O} / \mathrm{OH}^{-}[41,42]$.

To characterize the optical responses of $\mathrm{g}-\mathrm{C}_{3} \mathrm{~N}_{4}, \mathrm{~V}_{\mathrm{o}}-\mathrm{ZnO}$ and g- $\mathrm{C}_{3} \mathrm{~N}_{4} / \mathrm{V}_{\mathrm{o}}-\mathrm{ZnO}$ samples, UV-vis absorption spectra were measured at room temperature. As depicted in Fig. 4(a), the g- $\mathrm{C}_{3} \mathrm{~N}_{4} / \mathrm{V}_{0}-\mathrm{ZnO}$ hybrid photocatalysts displayed a long absorption tail extending from the visible to near-infrared (NIR) regions compared with that of pure $\mathrm{V}_{\mathrm{o}}-\mathrm{ZnO}$, indicating that the g- $\mathrm{C}_{3} \mathrm{~N}_{4} / \mathrm{V}_{\mathrm{o}}-\mathrm{ZnO}$ samples contain a high concentration of oxygen vacancies because of the doping of $\mathrm{O}$ sites of $\mathrm{ZnO}$ with $\mathrm{N}$ atoms [43]. It is noted that only a small proportion of $\mathrm{g}-\mathrm{C}_{3} \mathrm{~N}_{4}$ nanosheets in $\mathrm{V}_{\mathrm{o}} \mathrm{ZnnO}$ leads to a large extension of the optical absorption of $\mathrm{g}-\mathrm{C}_{3} \mathrm{~N}_{4} / \mathrm{V}_{\mathrm{o}}-\mathrm{ZnO}$ to the visible region. Moreover, the UV-vis-NIR absorption of 1 wt $\%$ g- $\mathrm{C}_{3} \mathrm{~N}_{4} / \mathrm{V}_{\mathrm{o}}-\mathrm{ZnO}$ is stronger than that of the other samples, suggesting that $1 \mathrm{wt} \%$ g- $\mathrm{C}_{3} \mathrm{~N}_{4} / \mathrm{V}_{\mathrm{o}}-\mathrm{ZnO}$ may exhibit higher photocatalytic activity. Because $\mathrm{ZnO}$ is a direct semiconductor, a plot of $\left(\alpha E_{\text {photon }}\right)^{2}$ versus the energy of the absorbed light provides the band gap of $\mathrm{V}_{\mathrm{o}}$-ZnO (where $\alpha$ and $E_{\text {photon }}$ are the absorption coefficient and discrete photon energy, respectively). Fig. 4(b) shows the calculated band gap of $\mathrm{V}_{\mathrm{o}}$-ZnO NPs is $\sim 3.09 \mathrm{eV}$, which is smaller than that of defect-free $\mathrm{ZnO}(3.24 \mathrm{eV})$ [11]. This band-gap nar-
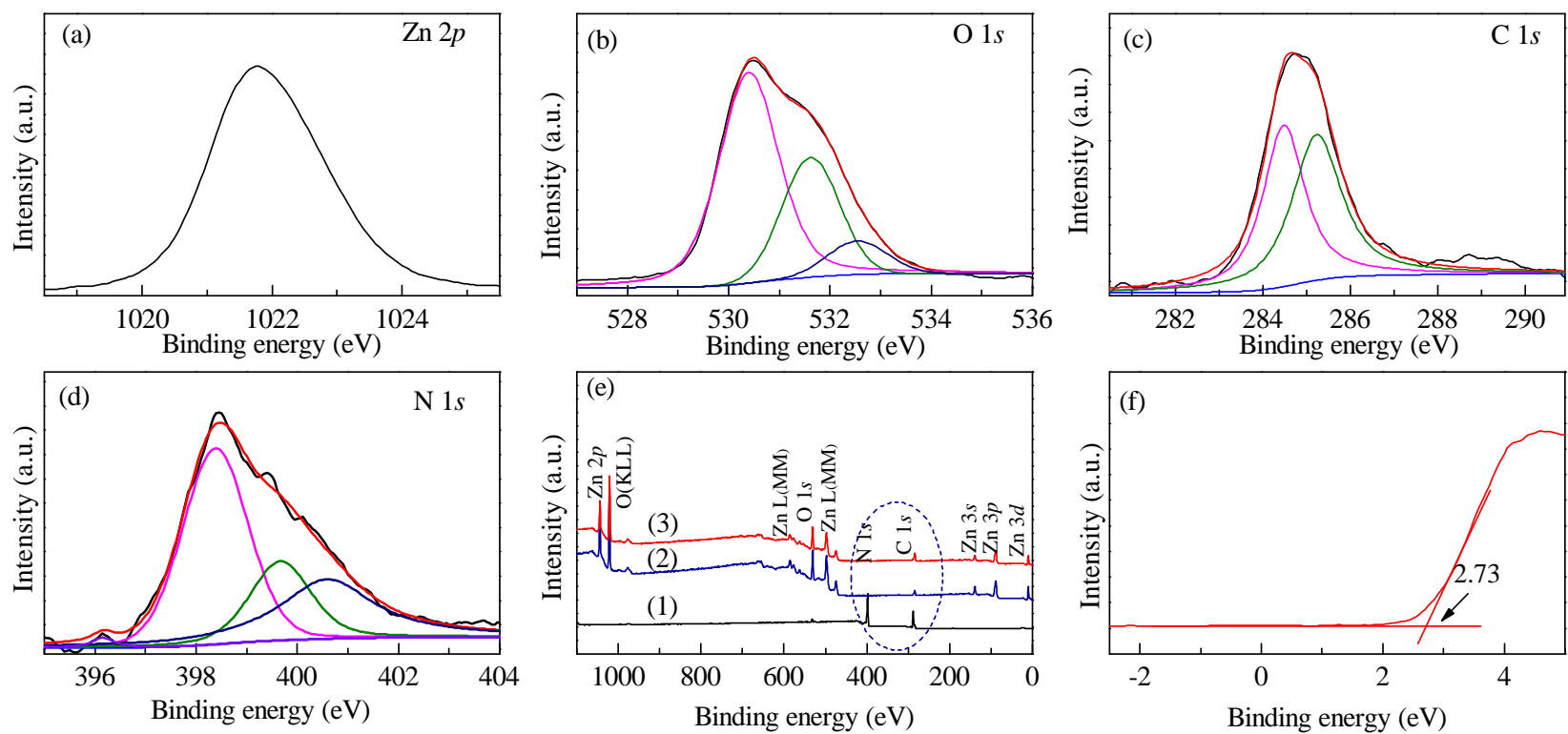

Fig. 3. Zn $2 p$ (a), $\mathrm{O} 1 s$ (b), C $1 s$ (c), and $\mathrm{N} 1 s$ (d) spectra measured for $1 \mathrm{wt} \% \mathrm{~g}-\mathrm{C}_{3} \mathrm{~N}_{4} / \mathrm{V}_{\mathrm{o}}-\mathrm{ZnO}$. (e) XPS survey spectra for g- $\mathrm{C}_{3} \mathrm{~N}_{4}(1), \mathrm{V}_{0}-\mathrm{ZnO}(2)$ and $1 \mathrm{wt} \% \mathrm{~g}-\mathrm{C}_{3} \mathrm{~N}_{4} / \mathrm{V}_{\mathrm{o}}-\mathrm{ZnO}$ (3). (f) Valence-band XPS measurement for $\mathrm{V}_{\mathrm{o}}-\mathrm{ZnO}$. 

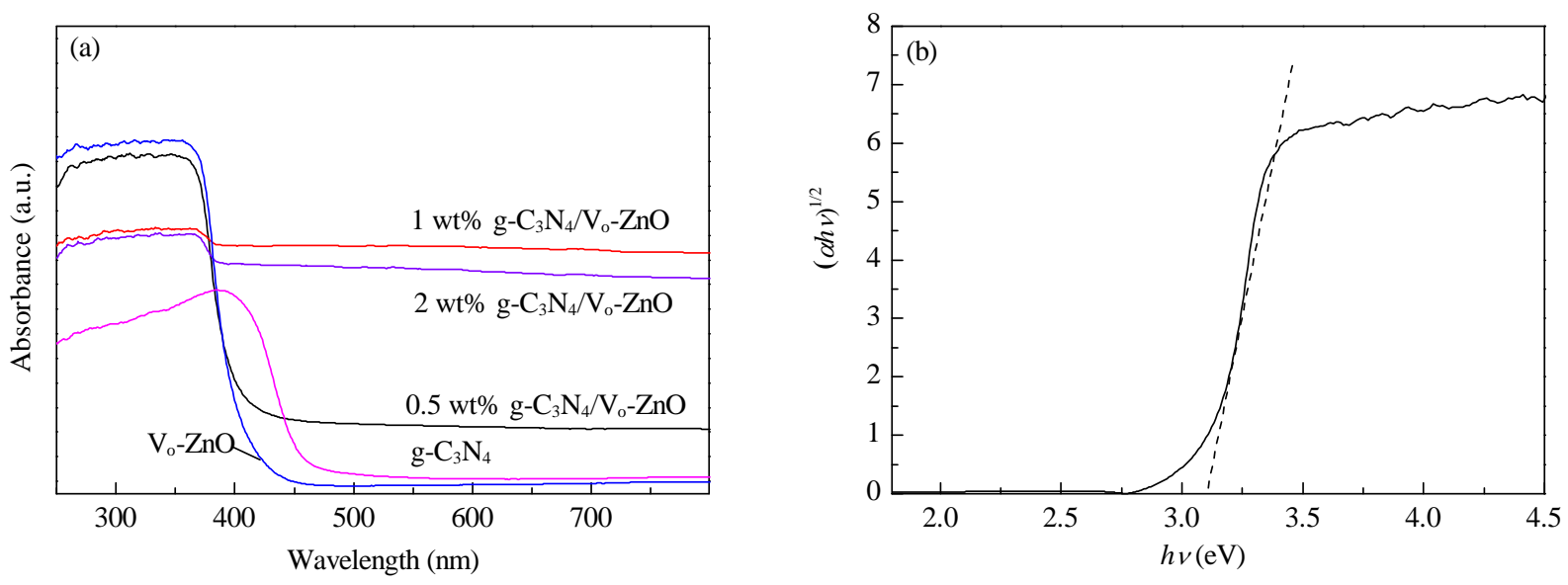

Fig. 4. (a) UV-vis DRS of pure g- $\mathrm{C}_{3} \mathrm{~N}_{4}, \mathrm{~V}_{0}-\mathrm{ZnO}$ and g- $\mathrm{C}_{3} \mathrm{~N}_{4} / \mathrm{V}_{0}-\mathrm{ZnO}$ composite photocatalysts. (b) Calculation of the band gap of $\mathrm{V}_{0}-\mathrm{ZnO}$.
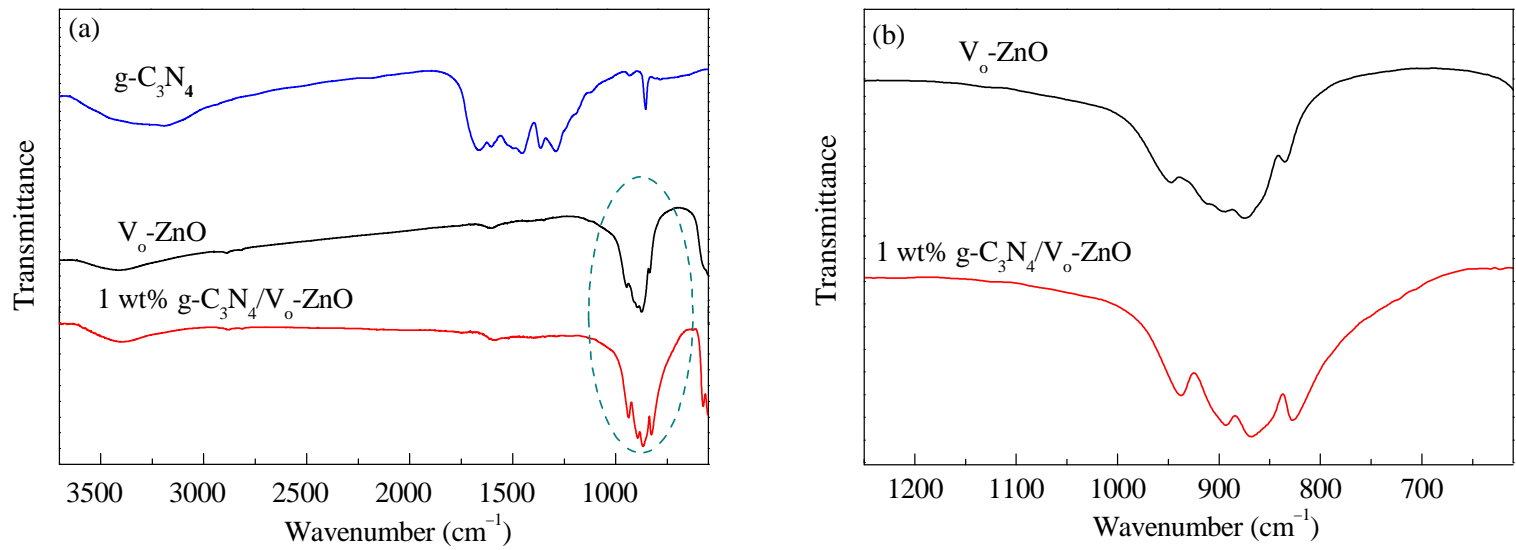

Fig. 5. (a) FT-IR spectra of as-prepared g- $\mathrm{C}_{3} \mathrm{~N}_{4}, \mathrm{~V}_{\mathrm{o}}-\mathrm{ZnO}$ and $1 \mathrm{wt} \% \mathrm{~g}-\mathrm{C}_{3} \mathrm{~N}_{4} / \mathrm{V}_{\mathrm{o}}-\mathrm{ZnO}$. (b) Magnification of the area in the ellipse in (a).

rowing can be attributed to the presence of oxygen vacancies in the $\mathrm{V}_{\mathrm{o}}$-ZnO NPs.

Figure 5(a) depicts FT-IR spectra of g- $\mathrm{C}_{3} \mathrm{~N}_{4}, \mathrm{~V}_{\mathrm{o}}-\mathrm{ZnO}$ and 1 $w \mathrm{t} \% \mathrm{~g}-\mathrm{C}_{3} \mathrm{~N}_{4} / \mathrm{V}_{\mathrm{o}}-\mathrm{ZnO}$. For $\mathrm{g}-\mathrm{C}_{3} \mathrm{~N}_{4}$, the peak at $808 \mathrm{~cm}^{-1}$ corresponds to the s-triazine ring system [44]. The peaks at 1243 and $1637 \mathrm{~cm}^{-1}$ are assigned to the $\mathrm{C}-\mathrm{N}$ and $\mathrm{C}=\mathrm{N}$ stretching vibrations, respectively [45]. The peak located near $900 \mathrm{~cm}^{-1}$ in the spectrum of $\mathrm{ZnO}$ can be attributed to the $\mathrm{Zn}-\mathrm{O}$ stretching mode. Meanwhile, the peaks at 1632 and $3200-3600 \mathrm{~cm}^{-1}$ originate from the presence of hydroxyl groups and water bound to the $\mathrm{ZnO}$ surface [46]. In addition, the absorption peak in the range of $600-900 \mathrm{~cm}^{-1}$ for $1 \mathrm{wt} \% \mathrm{~g}-\mathrm{C}_{3} \mathrm{~N}_{4} / \mathrm{V}_{\mathrm{o}}-\mathrm{ZnO}$ shift to lower wavenumber compared with that of $\mathrm{V}_{\mathrm{o}} \mathrm{ZnnO}$ (Fig. 5(b)). This indicates that the $\mathrm{C}-\mathrm{N}$ and $\mathrm{C}=\mathrm{N}$ bonds are weakened and the conjugated system of $\mathrm{g}-\mathrm{C}_{3} \mathrm{~N}_{4}$ is stretched to form a more widely conjugated system containing $\mathrm{V}_{\mathrm{o}}-\mathrm{ZnO}$ and g- $\mathrm{C}_{3} \mathrm{~N}_{4}$ in the hybrid photocatalyst. This is clear evidence that a covalent bond is formed between $\mathrm{g}-\mathrm{C}_{3} \mathrm{~N}_{4}$ and $\mathrm{V}_{\mathrm{o}}-\mathrm{ZnO}[36,44,47]$, which agrees well with the XPS results and further confirms that the as-prepared hybrid photocatalysts contain g- $\mathrm{C}_{3} \mathrm{~N}_{4}$. This strong coupling may facilitate efficient charge transfer and promoting photocatalytic activity.

To examine the paramagnetic characteristics of $1 \mathrm{wt} \%$ g- $\mathrm{C}_{3} \mathrm{~N}_{4} / \mathrm{V}_{\mathrm{o}}-\mathrm{ZnO}$ and $\mathrm{V}_{\mathrm{o}}-\mathrm{ZnO}$, EPR spectra were obtained at -143
${ }^{\circ} \mathrm{C}$. Fig. 6 reveals that $\mathrm{V}_{\mathrm{o}}-\mathrm{ZnO}$ exhibited a weak EPR signal with a $g$ factor of 2.00, which is characteristic of single-electron-trapped (paramagnetic) oxygen vacancies [48]. Compared with $\mathrm{V}_{\mathrm{o}}-\mathrm{ZnO}, 1$ wt $\%$ g- $\mathrm{C}_{3} \mathrm{~N}_{4} / \mathrm{V}_{\mathrm{o}}-\mathrm{ZnO}$ exhibits a more intense EPR signal at a similar position. The hybrid photocatalysts has a higher number of resonance peaks than $\mathrm{V}_{0}-\mathrm{ZnO}$. This indicates that there are more $\cdot \mathrm{O}_{2}$ - superoxide ions generated from oxygen or $-\mathrm{OH}$ groups and more oxygen vacancies in 1

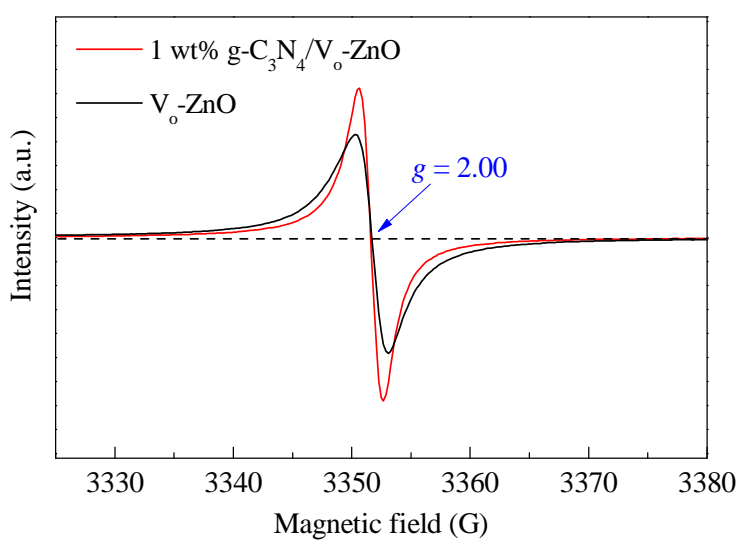

Fig. 6. X-band EPR spectra of $1 \mathrm{wt} \% \mathrm{~g}-\mathrm{C}_{3} \mathrm{~N}_{4} / \mathrm{V}_{\mathrm{o}}-\mathrm{ZnO}$ and $\mathrm{V}_{\mathrm{o}}-\mathrm{ZnO}$ samples recorded at $-143^{\circ} \mathrm{C}$. 
$w t \% g-\mathrm{C}_{3} \mathrm{~N}_{4} / \mathrm{V}_{\mathrm{o}}-\mathrm{ZnO}$ than in $\mathrm{V}_{\mathrm{o}}-\mathrm{ZnO}$ [49]. This observation is in good agreement with the results of XPS analysis.

\subsection{Photocatalytic property evaluation}

The photocatalytic activity and stability of the g- $\mathrm{C}_{3} \mathrm{~N}_{4} / \mathrm{V}_{\mathrm{o}}$-ZnO photocatalysts were evaluated by photodegradation of MO dye in aqueous solution under visible-light irradiation. For comparison, the photocatalytic activities of pure $\mathrm{V}_{\mathrm{o}}-\mathrm{ZnO}$ and $\mathrm{g}-\mathrm{C}_{3} \mathrm{~N}_{4}$ were also investigated under the same experimental conditions. Total concentrations of MO aqueous solutions were determined from UV-vis absorption measurements $(\lambda=464 \mathrm{~nm}) . c / c_{0}$ was used to describe the degradation efficiency, where $c$ is the concentration of MO at time $t$ and $c_{0}$ is the concentration of $\mathrm{MO}$ at adsorption equilibrium. Fig. 7(a) clearly shows that the $\mathrm{g}-\mathrm{C}_{3} \mathrm{~N}_{4} / \mathrm{V}_{\mathrm{o}}-\mathrm{ZnO}$ samples exhibited higher photocatalytic activities for MO degradation than $\mathrm{V}_{\mathrm{o}}-\mathrm{ZnO}$ and g- $\mathrm{C}_{3} \mathrm{~N}_{4}$. Among the $\mathrm{g}-\mathrm{C}_{3} \mathrm{~N}_{4} / \mathrm{V}_{\mathrm{o}}-\mathrm{ZnO}$ photocatalysts, that containing $1 \mathrm{wt} \% \mathrm{~g}-\mathrm{C}_{3} \mathrm{~N}_{4}$ showed the highest photocatalytic activity, photodegrading $93 \%$ of the MO in the aqueous solution after $60 \mathrm{~min}$ of visible-light irradiation. In contrast, $\mathrm{V}_{\mathrm{o}}-\mathrm{ZnO}$ displayed moderate photocatalytic MO degradation, and $\mathrm{g}-\mathrm{C}_{3} \mathrm{~N}_{4}$ showed negligible photocatalytic activity. These results demonstrate that $\mathrm{g}-\mathrm{C}_{3} \mathrm{~N}_{4}$ can effectively modify $\mathrm{ZnO}$ to improve its visible-light photocatalytic performance.

The photocatalytic degradation of HA by the same catalysts was also investigated (Fig. 7(b)). HA is a model compound for natural organic matter, and among the humic substances formed by the environmental breakdown of animal and vegetable matter. Total concentrations of HA were determined by UV-vis absorption measurements using the characteristic absorption wavelength of $\mathrm{HA}$ of $254 \mathrm{~nm}$. The $1 \mathrm{wt} \%$ g- $\mathrm{C}_{3} \mathrm{~N}_{4} / \mathrm{V}_{\mathrm{o}}-\mathrm{ZnO}$ photocatalyst showed good photocatalytic activity for HA, photodegrading $80 \%$ of the HA in the aqueous solution after $60 \mathrm{~min}$ of visible-light irradiation. Comparison of the photocatalytic activity of $1 \mathrm{wt} \%$ g- $\mathrm{C}_{3} \mathrm{~N}_{4} / \mathrm{V}_{\mathrm{o}}-\mathrm{ZnO}$ with reported catalysts [43,50-52] (Table 1 ) revealed that it exhibits high photocatalytic activity for dye degradation and shows potential for application in wastewater treatment.

After photoexcitation, holes with sufficient oxidation power

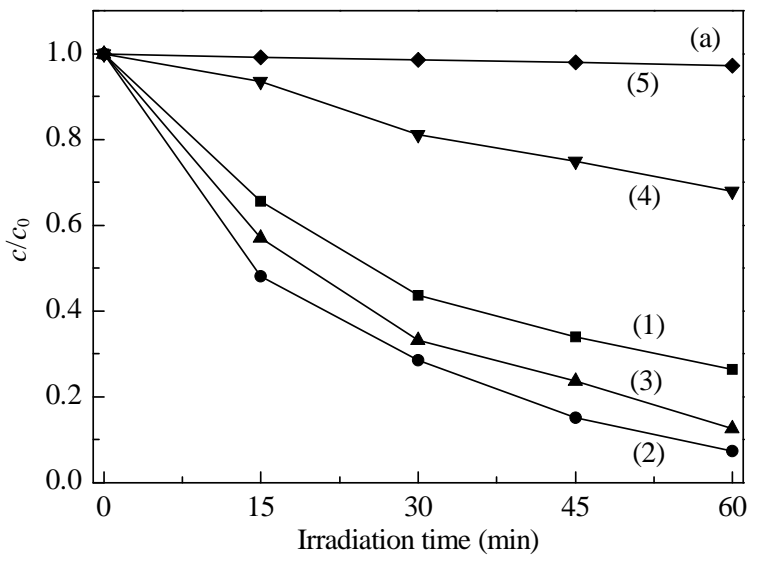

Table 1

Photocatalytic activities of different $\mathrm{g}-\mathrm{C}_{3} \mathrm{~N}_{4} / \mathrm{ZnO}$ photocatalysts under visible-light irradiation.

\begin{tabular}{|c|c|c|c|c|c|c|}
\hline Photocatalyst & Dye & $\begin{array}{l}C_{\text {photocatalyst }} \\
(\mathrm{mg} / \mathrm{mL})\end{array}$ & $\begin{array}{c}C_{\text {dye }} \\
(\mathrm{mg} / \\
\mathrm{L})\end{array}$ & $\begin{array}{l}\text { Time } \\
\text { (min) }\end{array}$ & $\begin{array}{c}\text { Degradation } \\
\text { efficiency } \\
(\%)\end{array}$ & Ref. \\
\hline $5.0 \mathrm{wt} \% \mathrm{~g}-\mathrm{C}_{3} \mathrm{~N}_{4} / \mathrm{ZnO}$ & RhB & 2 & 4.5 & 100 & 97 & [43] \\
\hline g- $\mathrm{C}_{3} \mathrm{~N}_{4} / \mathrm{ZnO} 15.0 \mathrm{wt} \%$ & RhB & 2 & 10 & 150 & 98 & [50] \\
\hline $\mathrm{g}-\mathrm{C}_{3} \mathrm{~N}_{4} / \mathrm{ZnO} 15.6 \%$ & MO & 3 & 4 & 80 & 97 & [51] \\
\hline $6.0 \% \mathrm{~g}-\mathrm{C}_{3} \mathrm{~N}_{4} / \mathrm{ZnO}$ & RhB & 1 & 7 & 150 & 75 & [52] \\
\hline $1.0 \mathrm{wt} \% \mathrm{~g}-\mathrm{C}_{3} \mathrm{~N}_{4} / \mathrm{V}_{\mathrm{o}}-\mathrm{ZnO}$ & MO & 1 & 10 & 60 & 93 & $\begin{array}{c}\text { this } \\
\text { work }\end{array}$ \\
\hline
\end{tabular}

in localized states within the band gap or VB can be either directly involved in the photocatalytic degradation reactions or generate active species. The reaction between TA and $\bullet \mathrm{OH}$ species in basic solution can generate $\mathrm{TAOH}$, which emits a unique PL signal with maximal intensity centered at $425 \mathrm{~nm}$ [53]. There is a linear relation between the fluorescence intensity of this peak and content of $\cdot \mathrm{OH}$ in a solution containing TA. Fig. 8(a) reveals that the fluorescence intensity of a solution of TA containing 1 wt $\%$ g- $\mathrm{C}_{3} \mathrm{~N}_{4} / \mathrm{V}_{\mathrm{o}}-\mathrm{ZnO}$ enhanced gradually with lengthening irradiation time, indicating an increase in the content of $\cdot 0 H$. Fig. 8(b) shows plots of PL intensity at $425 \mathrm{~nm}$ against irradiation time for solutions containing $\mathrm{TA}$ and $\mathrm{V}_{\mathrm{o}}-\mathrm{ZnO}$, g- $\mathrm{C}_{3} \mathrm{~N}_{4}$ and $\mathrm{g}-\mathrm{C}_{3} \mathrm{~N}_{4} / \mathrm{V}_{\mathrm{o}}-\mathrm{ZnO}$ with different contents of $\mathrm{g}-\mathrm{C}_{3} \mathrm{~N}_{4}$. For each sample, the PL intensity increased linearly with irradiation time. At a fixed time, $1 \mathrm{wt} \% \mathrm{~g}-\mathrm{C}_{3} \mathrm{~N}_{4} / \mathrm{V}_{\mathrm{o}}-\mathrm{ZnO}$ showed the highest content of $\cdot \mathrm{OH}$ among the five samples, which is consistent with results for photodegradation of MO over the photocatalysts. Therefore, the excellent visible-light-driven photocatalytic activity of the $\mathrm{g}-\mathrm{C}_{3} \mathrm{~N}_{4} / \mathrm{V}_{\mathrm{o}}-\mathrm{ZnO}$ photocatalyst might be ascribed to the presence of a suitable amount of g- $\mathrm{C}_{3} \mathrm{~N}_{4}$, which leads to a high concentration of oxygen vacancies in $\mathrm{ZnO}$, and facilitates the separation of photogenerated electrons and holes.

The stability of photocatalysts is another important factor for their practical application. To verify the stability and reusability of $\mathrm{g}-\mathrm{C}_{3} \mathrm{~N}_{4} / \mathrm{V}_{\mathrm{o}}-\mathrm{ZnO}$, the photocatalytic degradation of $\mathrm{MO}$ in the presence of $1 \mathrm{wt} \% \mathrm{~g}-\mathrm{C}_{3} \mathrm{~N}_{4} / \mathrm{V}_{0}-\mathrm{ZnO}$ was performed under

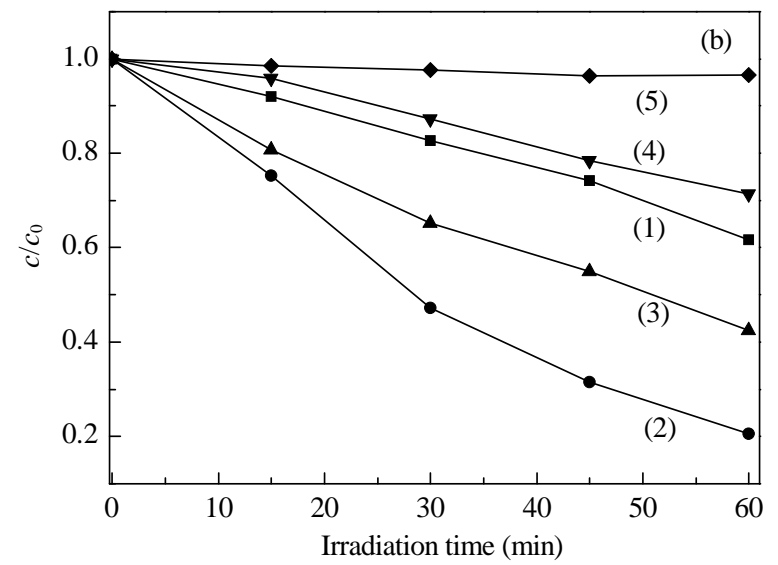

Fig. 7. Photodegradation of $\mathrm{MO}$ (a) and $\mathrm{HA}$ (b) over different samples under visible-light irradiation. (1) 0.5 wt $\%$ g- $\mathrm{C}_{3} \mathrm{~N}_{4} / \mathrm{V}_{\mathrm{o}}-\mathrm{ZnO}$; (2) 1 wt $\%$ g- $\mathrm{C}_{3} \mathrm{~N}_{4} / \mathrm{V}_{\mathrm{o}}-\mathrm{ZnO}$; (3) $2 \mathrm{wt} \%$ g- $\mathrm{C}_{3} \mathrm{~N}_{4} / \mathrm{V}_{\mathrm{o}}-\mathrm{ZnO}$; (4) $\mathrm{V}_{\mathrm{o}}-\mathrm{ZnO}$; (5) g- $\mathrm{C}_{3} \mathrm{~N}_{4}$. 

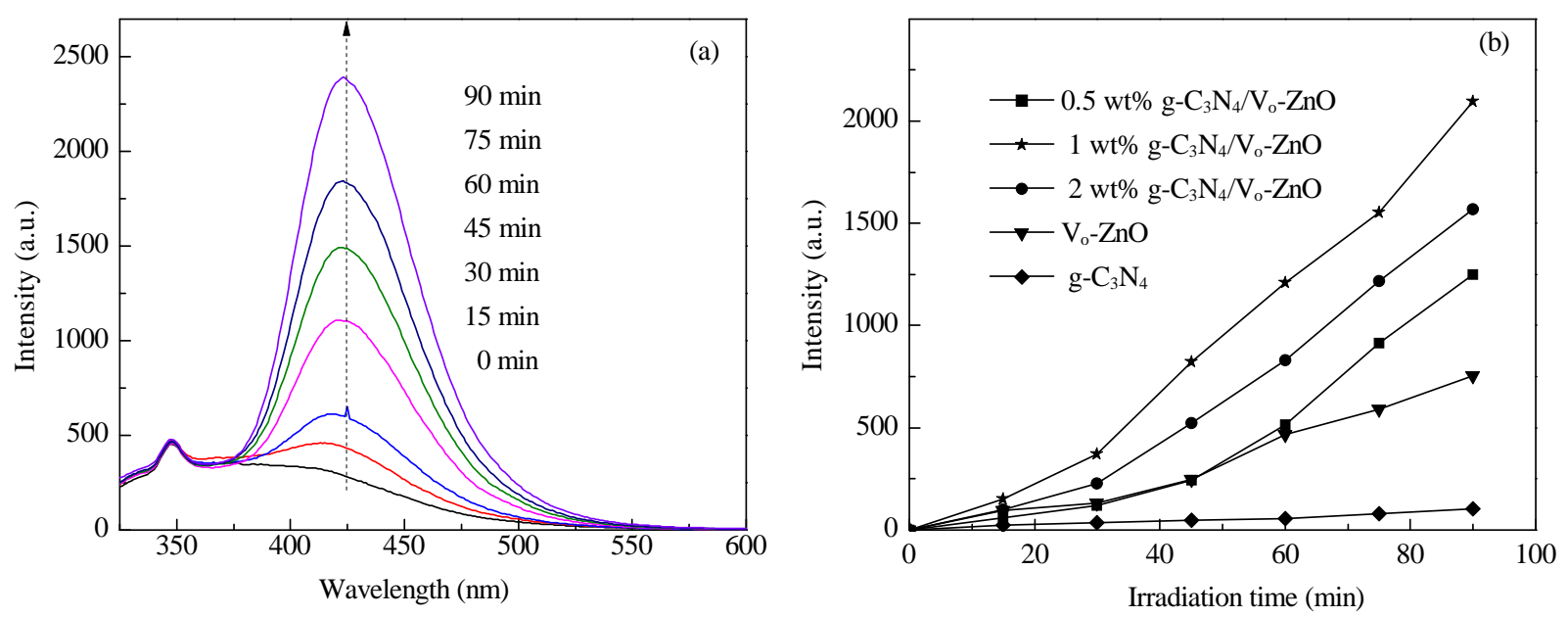

Fig. 8. (a) Photoluminescence spectra of 2 -hydroxy terephthalic acid generated in the presence of $1 \mathrm{wt} \%$ g- $\mathrm{C}_{3} \mathrm{~N}_{4} / \mathrm{V}_{\mathrm{o}}-\mathrm{ZnO}$ under visible-light irradiation. (b) Fluorescence intensity of solutions of terephthalic acid containing $\mathrm{V}_{0}-\mathrm{ZnO}$, g- $\mathrm{C}_{3} \mathrm{~N}_{4}$ and g- $\mathrm{C}_{3} \mathrm{~N}_{4} / \mathrm{V}_{0}-\mathrm{ZnO}$ with different contents of g-C $\mathrm{C}_{3} \mathrm{~N}_{4}$ under visible-light irradiation.

the same reaction conditions using recycled catalyst. As displayed in Fig. 9, after five MO photodegradation cycles, the catalyst did not exhibit any substantial loss of activity. Even after five degradation cycles, about $83.1 \%$ of the MO was degraded, confirming that the $\mathrm{g}-\mathrm{C}_{3} \mathrm{~N}_{4} / \mathrm{V}_{\mathrm{o}}-\mathrm{ZnO}$ photocatalyst is highly stable and not corroded during repeated photocatalytic degradation cycles.

\subsection{Proposed mechanism for photocatalytic activity enhancement}

To elucidate the role of oxygen vacancies in photocatalysis, the effect of oxygen vacancy concentration on the band structure of $\mathrm{V}_{0}-\mathrm{ZnO}$ was determined, as illustrated in Scheme 1 $[54,55]$. The oxygen vacancy $\left(\mathrm{V}_{0} \cdot *\right)$ defect energy levels used in Scheme 1 were calculated by Zheng et al. [56]. Scheme 1(a) reveals that the oxygen vacancy level is below the CB edge and has no obvious effect on the band gap of $\mathrm{ZnO}$ when the oxygen vacancy concentration is low. When numerous oxygen vacancies exist in $\mathrm{ZnO}$, the oxygen vacancy level becomes more delocalized and overlaps with the CB edge (Scheme 1(b)). As a result, the band gap of $\mathrm{V}_{\mathrm{o}} \mathrm{ZnO}$ is narrowed to $3.09 \mathrm{eV}$, which al-

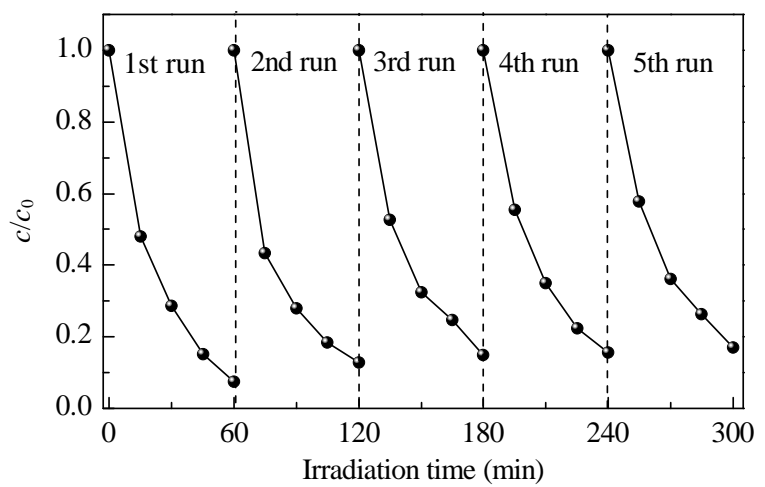

Fig. 9. Illustration of the working principle of multi-wavelength Raman spectroscopy of supported metal oxide. $\lambda_{\mathrm{RR}}$ and $\lambda_{\mathrm{NR}}$ refer to excitations resulting in resonance and non-resonance Raman, respectively. lows $\mathrm{ZnO}$ to harvest visible light more efficiently. These considerations help to explain why $1 \mathrm{wt} \% \mathrm{~g}-\mathrm{C}_{3} \mathrm{~N}_{4} / \mathrm{V}_{\mathrm{o}}-\mathrm{ZnO}$ has the strongest UV-vis-NIR absorption among the five samples in Fig. 4(a).

According to the VB XPS measurements for $\mathrm{V}_{\mathrm{o}}-\mathrm{ZnO}$, the photoexcited holes in the $\mathrm{VB}$ of $\mathrm{V}_{\mathrm{o}}-\mathrm{ZnO}(+2.73 \mathrm{eV})$ can oxidize $\mathrm{OH}^{-}$or $\mathrm{H}_{2} \mathrm{O}$ to ${ }^{\circ} \mathrm{OH}$. The $\mathrm{CB}$ and $\mathrm{VB}$ edge potentials of g- $\mathrm{C}_{3} \mathrm{~N}_{4}$ are -1.12 and $+1.57 \mathrm{eV}$ vs. NHE, respectively [57]. The $\mathrm{CB}$ potential of $\mathrm{g}-\mathrm{C}_{3} \mathrm{~N}_{4}$ is more negative than $E^{0}\left(\mathrm{O}_{2} /{ }^{\circ} \mathrm{O}_{2}-=-0.046 \mathrm{eV}\right.$ vs. NHE) [58], so the accumulated electrons in the $\mathrm{CB}$ of $\mathrm{g}-\mathrm{C}_{3} \mathrm{~N}_{4}$ can reduce $\mathrm{O}_{2}$ to yield ${ }^{\circ} \mathrm{O}_{2}-$. The $\mathrm{VB}$ position of g- $\mathrm{C}_{3} \mathrm{~N}_{4}$ is more negative than the standard redox potential of $E^{0}\left(\cdot{ }^{\circ} \mathrm{H} / \mathrm{OH}^{-}\right)(+1.99$ $\mathrm{eV}$ vs. NHE) [41,42], which suggests that the photogenerated holes on the surface of $\mathrm{g}-\mathrm{C}_{3} \mathrm{~N}_{4}$ cannot react with $\mathrm{OH}^{-} / \mathrm{H}_{2} \mathrm{O}$ to form $\cdot \mathrm{OH}$. However, under the experimental conditions, the results in Fig. 8(b) show that g- $\mathrm{C}_{3} \mathrm{~N}_{4} / \mathrm{V}_{0}-\mathrm{ZnO}$ produces a higher content of $\bullet \mathrm{OH}$ than pure $\mathrm{V}_{\mathrm{o}}-\mathrm{ZnO}$.

Based on the above information, to explain why incorporation of g- $\mathrm{C}_{3} \mathrm{~N}_{4}$ in $\mathrm{V}_{0}-\mathrm{ZnO}$ enhances its photocatalytic activity, we suggest a Z-scheme mechanism for the $\mathrm{g}-\mathrm{C}_{3} \mathrm{~N}_{4} / \mathrm{V}_{\mathrm{o}}-\mathrm{ZnO}$ hybrid photocatalyst (Scheme 2) [59]. Under visible-light irradiation, both $\mathrm{V}_{0}-\mathrm{ZnO}$ and $\mathrm{g}-\mathrm{C}_{3} \mathrm{~N}_{4}$ are excited. The photoexcited electrons in the $\mathrm{CB}$ of $\mathrm{V}_{\mathrm{o}}-\mathrm{ZnO}$ quickly transfer to the $\mathrm{VB}$ of $\mathrm{g}-\mathrm{C}_{3} \mathrm{~N}_{4}$, result- (a)

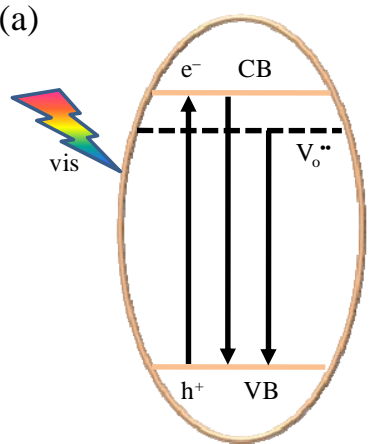

(b)

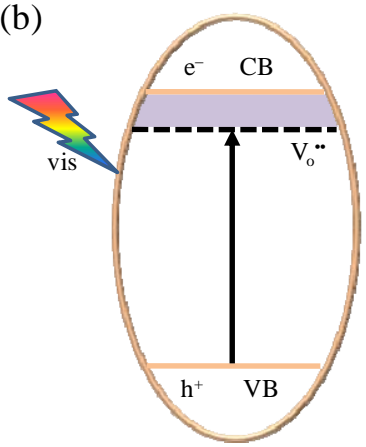

Scheme 1. Influence of oxygen vacancy concentration on the band structures of $\mathrm{ZnO}$. Low (a) and high concentration (b) of oxygen vacancies. 


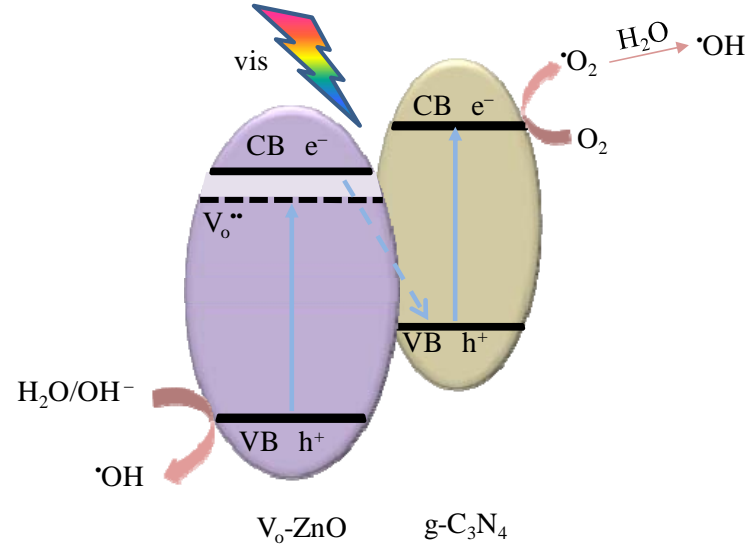

Scheme 2. Schematic illustration of the photocatalytic reaction mechanism of the $\mathrm{g}_{-} \mathrm{C}_{3} \mathrm{~N}_{4} / \mathrm{V}_{0}-\mathrm{ZnO}$ nanocomposite in the degradation of MO and HA in aqueous solution under visible-light irradiation.

ing in the recombination of the electrons in the $\mathrm{CB}$ of $\mathrm{V}_{\mathrm{o}}-\mathrm{ZnO}$ and photoexcited holes in the VB of $\mathrm{g}^{-} \mathrm{C}_{3} \mathrm{~N}_{4}$. Meanwhile, the photogenerated holes in the $\mathrm{VB}$ of $\mathrm{V}_{0}-\mathrm{ZnO}$ oxidize $\mathrm{OH}^{-}$to ${ }^{\circ} \mathrm{OH}$, while the electrons on the $\mathrm{CB}$ of $\mathrm{g}-\mathrm{C}_{3} \mathrm{~N}_{4}$ are captured by $\mathrm{O}_{2}$ to form ${ }^{\circ} \mathrm{O}_{2}$, which transforms into ${ }^{\circ} \mathrm{OH}$, promoting the degradation of pollutants. Our results clearly demonstrate that the presence of $\mathrm{g}-\mathrm{C}_{3} \mathrm{~N}_{4}$ in the $\mathrm{g}-\mathrm{C}_{3} \mathrm{~N}_{4} / \mathrm{V}_{0}-\mathrm{ZnO}$ nanocomposites can increase the efficiency of photogenerated electron-hole separation. Remarkably, the $1 \mathrm{wt} \% \mathrm{~g}-\mathrm{C}_{3} \mathrm{~N}_{4} / \mathrm{V}_{\mathrm{o}}-\mathrm{ZnO}$ catalyst showed little decrease in activity even after five cycles of use (Fig. 9), implying that $\mathrm{g}-\mathrm{C}_{3} \mathrm{~N}_{4} / \mathrm{V}_{\mathrm{o}}-\mathrm{ZnO}$ is stable and not photocorroded easily. Thus, charge carrier transfer is improved and recombination of photogenerated electron-hole pairs is effectively inhibited after $\mathrm{g}-\mathrm{C}_{3} \mathrm{~N}_{4}$ loading. This dramatically promotes the photodegradation efficiency of $\mathrm{g}-\mathrm{C}_{3} \mathrm{~N}_{4} / \mathrm{V}_{0}-\mathrm{ZnO}$ under visible-light irradiation.

\section{Conclusions}

We fabricated g- $\mathrm{C}_{3} \mathrm{~N}_{4} / \mathrm{V}_{0}-\mathrm{ZnO}$ photocatalysts using a scalable, economical and simple method. Compared with pure $\mathrm{V}_{0}-\mathrm{ZnO}$ and $\mathrm{g}-\mathrm{C}_{3} \mathrm{~N}_{4}$, the $\mathrm{g}-\mathrm{C}_{3} \mathrm{~N}_{4} / \mathrm{V}_{0}-\mathrm{ZnO}$ photocatalysts exhibit enhanced photocatalytic activity for degradation of organic contaminants under visible-light irradiation. On the basis of the experimental and characterization results, the introduction of g- $\mathrm{C}_{3} \mathrm{~N}_{4}$ into $\mathrm{V}_{\mathrm{o}}-\mathrm{ZnO}$ results in a high concentration of oxygen vacancies, which promotes visible-light absorption. Additionally, the formation of a strong coupling interface between g- $\mathrm{C}_{3} \mathrm{~N}_{4}$ and $\mathrm{V}_{\mathrm{o}}-\mathrm{ZnO}$ greatly improves the separation efficiency of photogenerated electron-hole pairs, resulting in high visible-light photocatalytic activity. The $1 \mathrm{wt} \%$ g- $\mathrm{C}_{3} \mathrm{~N}_{4} / \mathrm{V}_{0}-\mathrm{ZnO}$ sample showed the best catalytic activity among the five tested samples, and exhibited high photostability even after being recycled five times. Overall, our results indicate that the combination of $\mathrm{V}_{\mathrm{o}}-\mathrm{ZnO}$ and $\mathrm{g}-\mathrm{C}_{3} \mathrm{~N}_{4}$ could be an ideal system to enhance electron-hole separation, resulting in potential applications in environmental pollutant removal. The present approach can also be extended to design other highly efficient visible-light photocatalysts.

\section{Acknowledgments}

Support from the Chinese Academy of Science (2015SRG-HSC048) is gratefully acknowledged.

\section{References}

[1] Tong H, Ouyang S X, Bi Y P, Umezawa N, Oshikiri M, Ye J H. Adv Mater, 2012, 24: 229

[2] Kubacka A, Fernández-García M, Colón G. Chem Rev, 2012, 112: 1555

[3] Hu X L, Li G S, Yu J C. Langmuir, 2010, 26: 3031

[4] Yu C L, Yang K, Xie Y, Fan Q Z, Yu J C, Shu Q, Wang C Y. Nanoscale, 2013, 5: 2142

[5] Xu A W, Gao Y, Liu H Q.J Catal, 2002, 207: 151

[6] Fan C M, Peng Y, Zhu Q, Lin L, Wang R X, Xu A W. J Phys Chem C, 2013, 117: 24157

[7] Zhang Y, Deng B, Zhang T R, Gao D M, Xu A W.J Phys Chem C, 2010, 114: 5073

[8] Zeng S Y, Tang K B, Li T W, Liang Z H, Wang D, Wang Y K, Qi Y X, Zhou W W.J Phys Chem C, 2008, 112: 4836

[9] Daneshvar N, Salari D, Khataee A R.J Photochem Photobiol A, 2004, 162: 317

[10] Lu J, Wang H H, Dong Y F, Wang F Q, Dong S J. Chin J Catal (芦佳, 王辉虎, 董一帆, 王凡强, 董仕节. 催化学报), 2014, 35: 1113

[11] Guo M Y, Ng A M C, Liu F Z, Djurišić A B, Chan W K, Su H M, Wong K S. J Phys Chem C, 2011, 115: 11095

[12] Liu S W, Li C, Yu J G, Xiang Q J. CrystEngComm, 2011, 13: 2533

[13] Wang Y J, Wang Q S, Zhan XY, Wang F M, Safdar M, He J. Nanoscale, 2013, 5: 8326

[14] Liu H, Wu X F, Li X Q, Wang J, Fan X M. Chin J Catal (刘红, 鸟小凤, 李湘奇, 王婕, 范希梅. 催化学报), 2014, 35: 1997

[15] Bandara J, Tennakone K, Jayatilaka P P B. Chemosphere, 2002, 49: 439

[16] Guo H L, Zhu Q, Wu X L, Jiang Y F, Xie X, Xu A W. Nanoscale, 2015, 7: 7216

[17] Wang G M, Ling Y C, Li Y. Nanoscale, 2012, 4: 6682

[18] van Dijken A, Janssen A H, Smitsmans M H P, Vanmaekelbergh D, Meijerink A. Chem Mater, 1998, 10: 3513

[19] Eskizeybek V, Sarı F, Gülce H, Gülce A, Avcı A. Appl Catal B, 2012, 119-120: 197

[20] Li B X, Liu T X, Wang Y F, Wang Z F. J Colloid Interface Sci, 2012, 377: 114

[21] Wang X C, Maeda K, Chen X F, Takanabe K, Domen K, Hou Y D, Fu X Z, Antonietti M. J Am Chem Soc, 2009, 131: 1680

[22] Wang X C, Maeda K, Thomas A, Takanabe K, Xin G, Carlsson J M, Domen K, Antonietti M. Nat Mater, 2009, 8: 76

[23] Zhang Y J, Antonietti M. Chem Asian J, 2010, 5: 1307

[24] Gillan E G. Chem Mater, 2000, 12: 3906

[25] Hu J M, Cheng W D, Huang S P, Wu D S, Xie Z. Appl Phys Lett, 2006, 89: 261117

[26] Zhang Y J, Mori T, Ye J H, Antonietti M. J Am Chem Soc, 2010, 132: 6294

[27] Zang Y P, Li L P, Zuo Y, Lin H F, Li G S, Guan X F. RSC Adv, 2013, 3: 13646

[28] Yu J G, Wang S H, Low J X, Xiao W. Phys Chem Chem Phys, 2013, 15: 16883

[29] Liao W J, Murugananthan M, Zhang Y R. Phys Chem Chem Phys, 2015, 17: 8877

[30] Peng Y, Wang Y, Chen Q G, Zhu Q, Xu A W. CrystEngComm, 2014, 16: 7906 


\title{
Graphical Abstract
}

Chin. J. Catal., 2015, 36: 2135-2144 doi: 10.1016/S1872-2067(15)60985-8

\section{Enhanced visible-light photocatalytic activity of Z-scheme graphitic carbon nitride/oxygen vacancy-rich zinc oxide hybrid photocatalysts}

Yanan Liu, Ruixia Wang, Zhengkun Yang, Hong Du, Yifan Jiang, Congcong Shen, Kuang Liang, Anwu Xu* University of Science and Technology of China; College of Chi Zhou

Graphitic carbon nitride/oxygen vacancy-rich zinc oxide hybrid photocatalysts with enhanced photocatalytic activity for degradation of organic contaminants under visible-light irradiation have been fabricated.



Phys A, 2009, 94: 387

[46] Viswanatha R, Venkatesh T G, Vidyasagar C C, Arthoba Nayaka Y. Arch Appl Sci Res, 2012, 4: 480

[47] Liu W, Wang M L, Xu C X, Chen S F. Chem Eng J, 2012, 209: 386

[48] Walters A B, Na B K, Liu C C, Vannice M A.J Mol Catal A, 2000, 162: 287

[49] Ischenko V, Polarz S, Grote D, Stavarache V, Fink K, Driess M. Adv Funct Mater, 2005, 15: 1945

[50] Liu W, Wang M L, Xu C X, Chen S F, Fu X L. J Mol Catal A, 2013, 368-369: 9

[51] Sun J X, Yuan Y P, Qiu L G, Jiang X, Xie A J, Shen Y H, Zhu J F. Dalton Trans, 2012, 41: 6756

[52] Li X F, Li M, Yang J H, Li X Y, Hu T J, Wang J S, Sui Y R, Wu X T, Kong L N.J Phys Chem Solids, 2014, 75: 441

[53] Hu Y, Gao X H, Yu L, Wang Y R, Ning J Q Xu S J, Lou X W. Angew Chem Int Ed, 2013, 52: 5636

[54] Wang J P, Wang Z Y, Huang B B, Ma Y D, Liu Y Y, Qin X Y, Zhang X Y, Dai Y. ACS Appl Mater Interfaces, 2012, 4: 4024

[55] Ansari S A, Khan M M, Kalathil S, Nisar A, Lee J, Cho M H. Nanoscale, 2013, 5: 9238

[56] Zheng Y H, Chen C Q, Zhan Y Y, Lin X Y, Zheng Q, Wei K M, Zhu J F, Zhu Y J. Inorg Chem, 2007, 46: 6675

[57] Thomas A, Fischer A, Goettmann F, Antonietti M, Müller J O, Schlögl R, Carlsson J M. J Mater Chem, 2008, 18: 4893

[58] Bai Y, Wang P Q Liu J Y, Liu X J. RSC Adv, 2014, 4: 19456

[59] Zhou P, Yu J G, Jaroniec M. Adv Mater, 2014, 26: 4920

[44] Wang Y J, Shi R, Lin J, Zhu Y F. Energy Environ Sci, 2011, 4: 2922
[45] Li X F, Zhang J, Shen L H, Ma Y M, Lei W W, Cui Q L, Zou G T. Appl

\section{$\mathrm{Z}$ 型复合催化剂g- $\mathrm{C}_{3} \mathrm{~N}_{4} / \mathrm{V}_{\mathbf{0}}-\mathrm{ZnO}$ 光催化活性的研究}

\author{
刘亚男 ${ }^{\mathrm{a}}$, 王瑞霞 ${ }^{\mathrm{b}}$, 杨正坤 ${ }^{\mathrm{a}}$, 杜 虹 ${ }^{\mathrm{a}}$, 姜一帆 ${ }^{\mathrm{a}}$, 申丛丛 ${ }^{\mathrm{a}}$, 梁 况 ${ }^{\mathrm{a}}$, 徐安武 ${ }^{\mathrm{*}}{ }^{*}$ \\ $\mathrm{a}$ 中国科学技术大学合肥微尺度物质科学国家实验室, 安徽合肥 230026

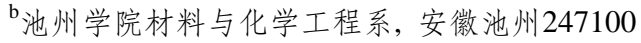

摘要：随着科学技术的不断进步和经济的快速发展, 人类对自然资源的需求量越来越大, 在开发利用自然资源的同时, 大量的有 机污染物也随之进入自然环境. 这些物质不仅污染环境、破坏生态, 更对人类的生活和健康带来了巨大的威胁. 研究证实, 半导体 光催化剂在光照条件下可以破坏有机污染物的分子结构, 最终将其氧化降解成 $\mathrm{CO}_{2} 、 \mathrm{H}_{2} \mathrm{O}$ 或其它不会对环境产生二次污染的小分 子, 从而净化水质. 近年来, 有关光催化降解有机污染物的报道日益增多. $\mathrm{ZnO}$ 作为一种广泛研究的光催化降解材料, 因其无毒、低 成本和高效等特点而具有一定的应用前景. 但是 $\mathrm{ZnO}$ 较大的禁带宽度 $(3.24 \mathrm{eV})$ 导致其只能吸收紫外光部分, 而对可见光的吸收效 
率很小, 极大地制约了其实际应用. 除此之外, $\mathrm{ZnO}$ 受光激发产生的电子-空穴分离效率较低、光催化过程中的光腐蚀严重也是制 约其实际应用的重要因素. 为了提高ZnO的光催化活性和稳定性, 本文合成了用 $g-\mathrm{C}_{3} \mathrm{~N}_{4}$ 修饰的氧空位型 $Z n O\left(g-\mathrm{C}_{3} \mathrm{~N}_{4} / \mathrm{V}_{\mathrm{o}}-\mathrm{ZnO}\right)$ 复合 催化剂, 在有效调控 $\mathrm{ZnO}$ 半导体能带结构的同时, 通过负载一定量的 $\mathrm{g}-\mathrm{C}_{3} \mathrm{~N}_{4}$ 以降低光生电子-空穴对的复合速率和反应过程中 $\mathrm{ZnO}$ 的光腐蚀, 增强催化剂的光催化活性和稳定性.

本文首先合成前驱体 $\mathrm{Zn}(\mathrm{OH}) \mathrm{F}$, 然后焙烧三聚氧胺和 $\mathrm{Zn}(\mathrm{OH}) \mathrm{F}$ 的混合物得到 $\mathrm{g}^{-} \mathrm{C}_{3} \mathrm{~N}_{4} / \mathrm{V}_{\mathrm{o}}-\mathrm{ZnO}$ 复合催化剂, 并采用电子顺磁共振 波谱(EPR)、紫外-可见光谱(UV-vis)、高分辨透射电镜(HRTEM)和傅里叶变换红外光谱(FT-IR)等表征了它们的结构及其性质. EPR 结果表明, $\mathrm{ZnO}$ 焙烧后具有一定浓度的氧空位, 导致其禁带宽度由 $3.24 \mathrm{eV}$ 降至 $3.09 \mathrm{eV}$, 因而提高了 ZnO对可见光的吸收效率. UV-vis结果显示, $\mathrm{V}_{\mathrm{o}}-\mathrm{ZnO}$ 复合g- $\mathrm{C}_{3} \mathrm{~N}_{4}$ 后对可见光的吸收显著增强. HRTEM和FT-IR 结果均表明, g- $\mathrm{C}_{3} \mathrm{~N}_{4}$ 纳米片和 $\mathrm{V}_{\mathrm{o}}-\mathrm{ZnO}$ 颗粒之间 通过共价键形成了强耦合, 这对 $-\mathrm{C}_{3} \mathrm{~N}_{4} / \mathrm{V}_{\mathrm{o}}-\mathrm{ZnO}$ 复合催化剂中光生载流子的传送和光生电子-空穴对的有效分离起到重要作用. 可 见光催化降解甲基橙(MO)和腐殖酸(HA)的实验进一步证明, g- $\mathrm{C}_{3} \mathrm{~N}_{4} / \mathrm{V}_{\mathrm{o}}-\mathrm{ZnO}$ 复合材料具有较好的光催化活性, 优于单一的 $\mathrm{g}-\mathrm{C}_{3} \mathrm{~N}_{4}$ 或 $\mathrm{V}_{\mathrm{o}}-\mathrm{ZnO}$ 材料. 同时还发现, $\mathrm{g}-\mathrm{C}_{3} \mathrm{~N}_{4}$ 的负载量对光催化活性有显著影响, 当氮化碳的负载量为 $1 \mathrm{wt} \%$ 时, 所制材料具有最高的光催 化活性: 可见光照射 $60 \mathrm{~min}$ 后, MO降解率可达到 $93 \%$, HA降解率为 $80 \%$. 复合材料光催化活性的增强一方面是因为氧空位的形成 减小了 $\mathrm{ZnO}$ 的禁带宽度, 使得 $\mathrm{ZnO}$ 对可见光的吸收能力大大增强; 另一方面, $\mathrm{g}-\mathrm{C}_{3} \mathrm{~N}_{4}$ 和 $\mathrm{V}_{0}-\mathrm{ZnO}$ 的能带符合了 $\mathrm{Z}$ 型催化机理所需的有 效能带匹配, 使得光生电子-空穴对得到了有效的分离, 从而提高了光催化活性.

降解MO的循环实验表明, g- $\mathrm{C}_{3} \mathrm{~N}_{4} / \mathrm{V}_{\mathrm{o}}-\mathrm{ZnO}$ 催化剂具有很好的稳定性且不容易发生光腐蚀. 与此同时, 我们对比了用不同方法 制备的g- $\mathrm{C}_{3} \mathrm{~N}_{4} / \mathrm{ZnO}$ 材料的催化性能. 结果显示, 本文制备的g- $\mathrm{C}_{3} \mathrm{~N}_{4} / \mathrm{V}_{\mathrm{o}}-\mathrm{ZnO}$ 复合材料具有更好的降解效率. 总体而言, 对于降解有 机污染物, g- $\mathrm{C}_{3} \mathrm{~N}_{4} / \mathrm{V}_{0}-\mathrm{ZnO}$ 可能是一个更为有效可行的催化体系. 此外, 本文也为设计与制备其他新型光催化剂提供了一条新的 思路.

关键词: 氧空位氧化锌; 石墨化氮化碳; 复合光催化剂; 光降解; Z型

收稿日期: 2015-08-16. 接受日期: 2015-09-25. 出版日期: 2015-12-20.

*通讯联系人. 电话/传真：(0551)63602346; 电子信箱：anwuxu@ustc.edu.cn

基金来源：国家重点基础研究发展计划(2011CB933700); 国家自然科学基金(21271165).

本文的英文电子版由Elsevier出版社在ScienceDirect上出版(http://www.sciencedirect.com/science/journal/18722067). 